\title{
SYNTHESIS OF RESORCINOLIC LIPIDS BEARING STRUCTURAL SIMILARITIES TO CYTOSPORONE A
}

\author{
Edson dos Anjos dos Santos, Adilson Beatriz e Dênis Pires de Lima*
}

Departamento de Química, Centro de Ciências Exatas e Tecnlogia, Universidade Federal Mato Grosso do Sul, CP 549, 79074-460

Campo Grande - MS, Brasil

Maria Rita Marques e Carla Braga Leite

Departamento de Morfofisiologia, Centro de Ciências Biológicas, Universidade Federal Mato Grosso do Sul, CP 549, 79021-400

Campo Grande - MS, Brasil

Recebido em 23/12/08; aceito em 27/3/09; publicado na web em 4/9/09

\begin{abstract}
SYNTHESIS OF RESORCINOLIC LIPIDS BEARING STRUCTURAL SIMILARITIES TO CYTOSPORONE A. Inspired by the structure and biological activities of resorcinolic lipids and, particularly cytosporone A- a potent inhibitor of plantule germination and growth, we have performed the synthesis of the analogs 3-heptyl-3-hydroxy-5,7-dimethoxy-2-benzofuran-1(3H)-one (1) and 3-heptyl-3-hydroxy-4,6-dimethoxy-2-benzofuran-1(3H)-one (2). The intermediates and products were submitted to allelopathic test using Lactuca sativa L. seeds. Target compound $\mathbf{1}$ showed an inhibitory effect on germination and growth of hypocotyl and radicle in milimolar range.
\end{abstract}

Keywords: resorcinolic lipid; cytosporone A; allelopathic activity.

\section{INTRODUCTION}

Resorcinolic lipids belong to one of the most investigated class of phenolic lipids owing to the great abundance in nature and their biological activities. ${ }^{1}$ These compounds present antibiotic, ${ }^{2}$ antifungal, ${ }^{3}$ molluscicidal, ${ }^{4}$ antitumor, ${ }^{5,6}$ anthelmintic, ${ }^{7}$ antiffedant ${ }^{8}$ and, antioxidant ${ }^{9}$ activities. Figure 1 shows the structure of cytosporone A, a potent inhibitor of factors affecting the process germination and growth of plants at very low concentration. The compound is an octaketide isolated from endophytic and phytopathogenic fungi and it is found in two tautomeric forms 3,5-dihydroxy-2-octanoylphenyl acetic acid (I) and the cyclic ester 1-heptyl-1,6,8-trihydroxy-1,4dihydro-3H-isochromen-3-one (II). ${ }^{10}$

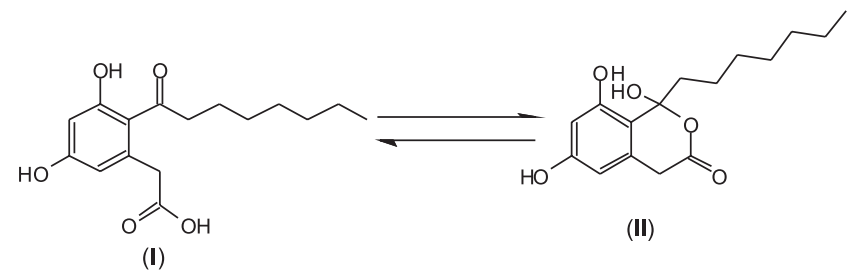

Figure 1. Tautomeric forms for cytosporone A

As part of a program on the chemistry of naturally occurring phenolic lipids and their synthetic derivatives, our research group has been submitting some of these compounds to biological assay. In this work we have focused our attention on the possibility of preparing new environmentally friend herbicides with comparable activities to those commercially available and, eventually use them as prototypes for development of new products. Therefore we have devised the synthesis of the compound 3-heptyl-3-hydroxy-5,7-dimethoxy-2benzofuran-1(3H)-one (1) together with its isomer 3-heptyl-3-hydroxy-4,6-dimethoxy-2-benzofuran-1(3H)-one (2) bearing structural similarities to cytosporone A (Figure 2). Additionally, as allelopathic activity suggests herbicide potential, we also submitted the intermedi-

*e-mail: dlima@nin.ufms.br ates and final products to this test. The choice for these targets was based on the possibility of obtaining structural analogs possessing similar or superior biological activity to that of cytosporone A and also carrying out studies on their molecular-structural aspects.

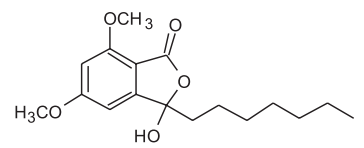

(1)<smiles>CCCCCCCC1(O)OC(=O)c2cc(OC)cc(OC)c21</smiles>

(2)
Figure 2. Structure of target molecules (1)

\section{RESULTS AND DISCUSSION}

\section{Syntheses}

As shown in Scheme 1, commercial starting material 3 was submitted to acid catalyzed esterification in order to produce 4. By employing Vilsmeier-Haack procedure compound $\mathbf{5}$ was obtained, reduced by $\mathrm{NaBH}_{4}$ and, treated with acid solution to promote the formation of lactone 6. Compounds 4-6 have been prepared according to general procedure described in literature. ${ }^{11-13}$ After oxidation of 6 in alkaline medium and acidification, the diacid 7 was achieved and submitted to treatment with acetic anhydride to give the dimethoxyphthalic anhydride $\mathbf{8}$. Grignard reaction of $\mathbf{8}$ with 1-bromoheptane$\mathrm{Mg}^{0}$ gave a mixture of the isomeric products 1 (20\%) and $2(17 \%)$. This regioselectivity, although low, is likely to be originated from the steric hindrance encountered by the nucleophile attack to the anhydride carbonyl adjacent to the methoxyl group. The structures of all intermediates and final products were elucidated by spectroscopic methods or otherwise by comparison with data in literature.

\section{Spectroscopic results}

NMR and/or IR data for compounds 4-7 were compared to literature. ${ }^{13-15}$ FT-IR spectrum of compound $\mathbf{8}$ showed two C-O stretching bands at $1766 \mathrm{~cm}^{-1}$ and $1839 \mathrm{~cm}^{-1}$ while ${ }^{13} \mathrm{C}$ NMR spectrum showed 
<smiles>CCOC(=O)c1cc(OC)cc(OC)c1</smiles>

(3)

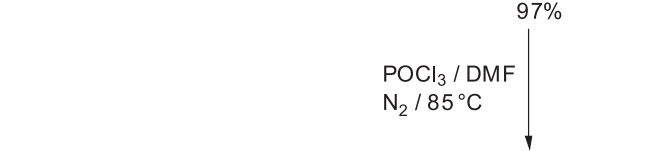<smiles>COc1cc(OC)c2c(c1)C(=O)OCC21COCCO1</smiles>

(6)

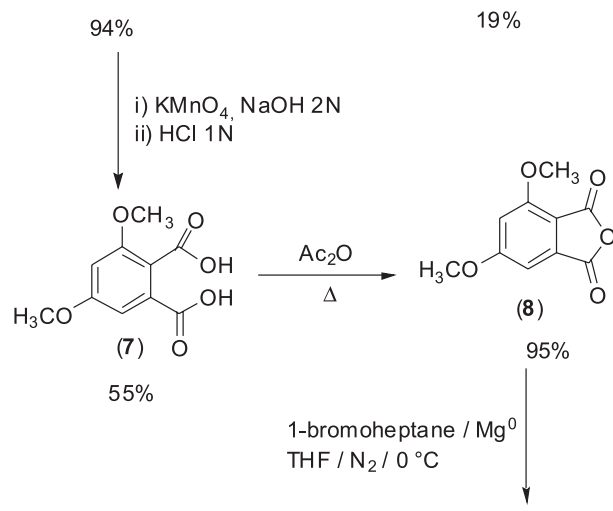<smiles>COc1cc(OC)c2c(c1)C(=O)OC2(C)O</smiles>

Scheme 1. Synthetic route for the preparation of 1 and 2

signals at $168.3 \mathrm{ppm}(\mathrm{C}=\mathrm{O}-1)$ and $163.1 \mathrm{ppm}(\mathrm{C}=\mathrm{O}-2)$ assigned to anhydride moiety of molecule.

${ }^{1} \mathrm{H}$ NMR and ${ }^{13} \mathrm{C}$ NMR chemical shifts of compounds $\mathbf{1}$ and $\mathbf{2}$ were unequivocally attributed by assistance of bidimensional experiments gHSQC and gHMBC (Figure 3 and Table 1). It was observed in the spectrum of compound $\mathbf{1}$ correlations between $\mathrm{H}-1$ ' to $\mathrm{C}-3 \mathrm{a}$ and $\mathrm{C}-3$ and, especially between $\mathrm{H}-4$ to $\mathrm{C}-3 \mathrm{a}$ confirming the insertion of the alkyl chain at C-3. Regarding methoxyl signals, it was identified interactions of methyl hydrogens to C-7 and C-5, respectively. In the spectrum of compound $\mathbf{2}$ is important to note the correlations of $\mathrm{H}-1$ ' to $\mathrm{C}-3 \mathrm{a}$ and to $\mathrm{C}-3$ and $\mathrm{H}-7$ to $\mathrm{C}-3 \mathrm{a}$. Aromatic hydrogens have larger values than those in compound 1 , caused by electronic effects of the carbonyl attached to $\mathrm{C}-1$. Methoxyls' chemical shifts were assigned by observing the correlations of their methyl groups to C-4 and C-6, respectively.

\section{Allelopathic activity}

With exception of starting material 3 all compounds were evaluated. Only compound $\mathbf{1}$ showed an important effect on Lactuca sativa L. seed germination test at concentration of $3.2 \mathrm{mM}$. Test of inhibition of the hypocotyl and radicle growth showed that compounds $\mathbf{1}$ and $\mathbf{4}$ were the most active at concentrations of 3.2 $\mathrm{mM}$ and $9.5 \mathrm{mM}$ respectively. It is also worth to mention that all plantules treated with intermediates $\mathbf{4}$ and $\mathbf{5}$ suffered tissue necrosis at all tested concentrations.

Nelson and Getsinger tested many herbicides against the invasive species wild taro (Colocasia esculenta $\mathrm{L}$. Schott ${ }^{16}$ and, supported by

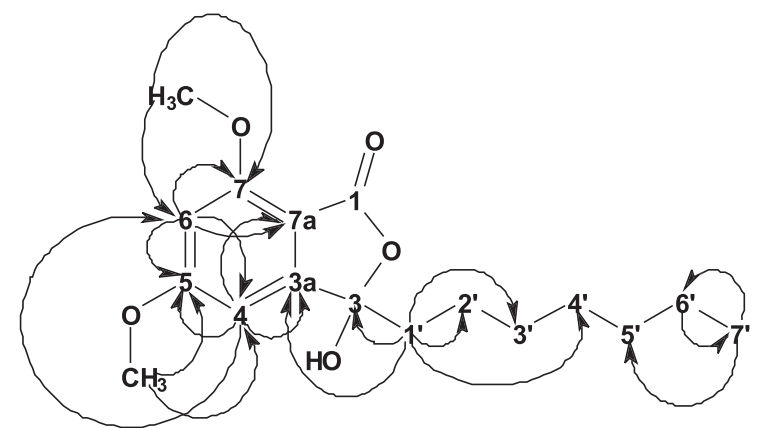

3-heptyl-3-hydroxy-5,7-dimethoxy-2-benzofuran-1(3H)-one (1)

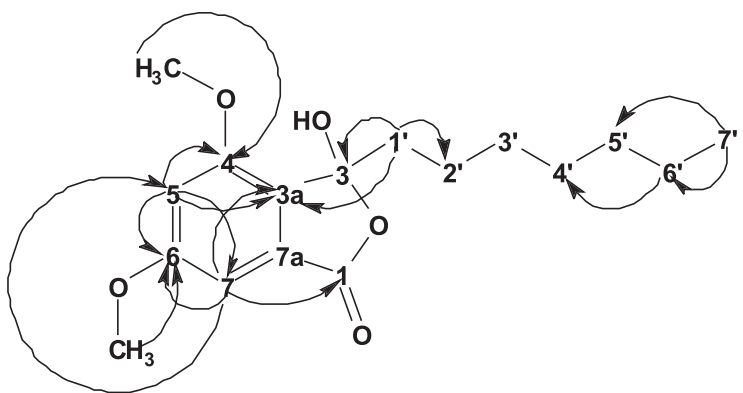

3-heptyl-3-hydroxy-4,6-dimethoxy-2-benzofuran-1(3H)-one (2)

Figure 3. Long range proton-carbon connectivity network found in the gHM$B C$ spectrum of compounds $\mathbf{1}$ and $\mathbf{2}$, arrows point from $\mathrm{H}$ to $\mathrm{C}$

their results we can suggest that compound $\mathbf{1}$ has herbicidal potential due to its activity at milimolar concentration.

\section{CONCLUSION}

Surveying the data presented one can conclude that compound 1 seems to be a possible prototype for future studies addressed to the synthesis of new weed agents based on its structural framework. Remarkably, compound $\mathbf{2}$ after being tested at the same concentrations as $\mathbf{1}$ showed no substantial growth inhibition rate meaning that this activity is not entirely predictable. Therefore it is also worthwhile to investigate the mechanism of action of these compounds and to look for more potent derivatives by setting up a complete structureactivity relationship. The synthesis suffers from the disadvantage of a moderate overall yield, originating mainly from the variable yields of the Vilsmeier-Haack reaction. However, the procedure is being investigated by using different reaction conditions.

\section{EXPERIMENTAL}

\section{General methods}

Silica gel (Merck 230-400 mesh) was used for chromatography column. NMR spectra were recorded in $\mathrm{CDCl}_{3}$ or $\mathrm{CD}_{3} \mathrm{OD}$ solutions on a Bruker DPX-300 instrument. All chemical shifts are referenced to TMS. IR spectra (KBr pellets) were recorded on a FTIR MB100 Boomed spectrophotometer. Melting points were determined on a Uniscience melting point apparatus.

Ethyl 3,5-dimethoxybenzoate (4) ${ }^{11}$

The product was colorless oil at room temperature. Yield $=97 \%$. - IR $\left(\mathrm{KBr}, \mathrm{cm}^{-1}\right): \overline{\mathrm{v}}_{\max }=3028,2906-2979,2839,1716 .-{ }^{1} \mathrm{H} \mathrm{NMR}$ $\left(\mathrm{CDCl}_{3}\right): \delta=1.36\left(\mathrm{t}, J=7.0 \mathrm{~Hz}, 3 \mathrm{H}, \mathrm{CH}_{3}\right), 3.80\left(\mathrm{~s}, 6 \mathrm{H}, 3,5-\mathrm{OCH}_{3}\right)$, $4.34\left(\mathrm{q}, J=7.0 \mathrm{~Hz}, 2 \mathrm{H}, \mathrm{CH}_{2}\right), 6.62(\mathrm{~d}, 1 \mathrm{H}, J=2.3 \mathrm{~Hz}, 4-\mathrm{H}), 7.17(\mathrm{~d}, J=$ $2.3 \mathrm{~Hz}, 2 \mathrm{H}, 2,6-\mathrm{H}) .{ }^{13} \mathrm{C} \mathrm{NMR}\left(75 \mathrm{MHz}, \mathrm{CDCl}_{3}\right): \delta=14.2\left(\mathrm{CH}_{3}\right), 55.5$ 
Table 1. NMR Data ${ }^{a}$ and proton-carbon connectivity network found in the gHSQC e gHMBC spectrum of compounds $\mathbf{1}$ and $\mathbf{2}$

\begin{tabular}{|c|c|c|c|c|c|c|}
\hline \multirow{2}{*}{ Position } & \multicolumn{3}{|c|}{ Compound 1} & \multicolumn{3}{|c|}{ Compound 2} \\
\hline & $\delta_{\mathrm{C}}$ & $\delta_{\mathrm{H}}$, mult, $J(\mathrm{~Hz})$ & $\mathrm{gHMBC}^{\mathrm{b}}$ & $\delta_{\mathrm{C}}$ & $\delta_{\mathrm{H}}$, mult, $J(\mathrm{~Hz})$ & $\mathrm{gHMBC}^{\mathrm{b}}$ \\
\hline 1 & 166.2 & - & - & 168.3 & - & - \\
\hline 2 & - & - & - & - & - & - \\
\hline 3 & 105.5 & - & - & 107.4 & 1.74, bs $(\mathrm{OH})$ & - \\
\hline $3 a$ & 153.9 & - & - & 128.7 & - & - \\
\hline 4 & 98.1 & $6.53, \mathrm{~d}, 1.73$ & $3 a, 5,6,7 a$ & 155.5 & - & - \\
\hline $4-\mathrm{OCH}_{3}$ & - & - & - & 55.9 & $3.88, \mathrm{~s}$ & 4 \\
\hline 5 & 167.1 & - & - & 105.2 & $6.67, \mathrm{~d}, 1.7$ & $3 a, 4,6,7$ \\
\hline $5-\mathrm{OCH}^{3}$ & 56.0 & $3.89, \mathrm{~s}$ & 4,5 & - & - & - \\
\hline 6 & 99.2 & $6.42, \mathrm{~d}, 1.73$ & $4,5,7,7 \mathrm{a}$ & 163.4 & - & - \\
\hline $6-\mathrm{OCH}_{3}$ & - & - & - & 56.0 & $3.85, \mathrm{~s}$ & 6 \\
\hline 7 & 159.0 & - & - & 98.8 & $6.87, \mathrm{~d}, 1.7$ & $1,3 a, 5,6$ \\
\hline $7 \mathrm{a}$ & 107.0 & - & - & 129.7 & - & - \\
\hline $7-\mathrm{OCH}_{3}$ & 56.0 & $3.90, \mathrm{~s}$ & 6,7 & - & - & - \\
\hline $1^{\prime}$ & 38.8 & $1.96-2.13, \mathrm{~m}$ & $2^{\prime}, 3,3 \mathrm{a}, 3^{\prime}, 4^{\prime}$ & 37.3 & - & $2^{\prime}, 3,3 \mathrm{a}$ \\
\hline $2^{\prime}$ & 23.2 & $1.09-1.36, \mathrm{~m}$ & - & 23.4 & $1.08, \mathrm{~m}$ & - \\
\hline $3^{\prime}$ & 29.3 & $1.19, \mathrm{~m}$ & - & 30.0 & $1.23, \mathrm{~m}$ & - \\
\hline $4^{\prime}$ & 29.0 & $1.19, \mathrm{~m}$ & - & 29.2 & $1.23, \mathrm{~m}$ & - \\
\hline 5 & 31.6 & $1.17, \mathrm{~m}$ & - & 31.6 & $1.22, \mathrm{~m}$ & - \\
\hline $6^{\prime}$ & 22.6 & $1.20, \mathrm{~m}$ & $7^{\prime}$ & 22.6 & $1.24, \mathrm{~m}$ & $4^{\prime}$ \\
\hline 7 ' & 14.0 & $0.83, \mathrm{t}, 6.65$ & $5^{\prime}, 7^{\prime}$ & 14.0 & $0.84, \mathrm{t}, 6.6$ & $5^{\prime}, 6^{\prime}$ \\
\hline
\end{tabular}

a $300 / 75 \mathrm{MHz}{ }^{1} \mathrm{H} /{ }^{13} \mathrm{C}$ and $\delta\left({ }^{1} \mathrm{H},{ }^{13} \mathrm{C}\right)$ in ppm relative to TMS. ${ }^{\text {b }} \delta_{\mathrm{H}}$ to $\delta_{\mathrm{C}}$.

$\left(3,5-\mathrm{OCH}_{3}\right), 61.1\left(\mathrm{CH}_{2}\right), 105.5(\mathrm{C}-4), 107.1(\mathrm{C}-2,6), 132.3(\mathrm{C}-1), 160.6$ $(\mathrm{C}-3,5), 166.3(\mathrm{C}=\mathrm{O})$. The NMR data were compared to literature. ${ }^{14}$

Ethyl 2-formyl-3,5-dimethoxybenzoate $(\mathbf{5})^{13}$

M. p. $=136^{\circ} \mathrm{C}$ (lit., $\left.132^{\circ} \mathrm{C}\right) ;{ }^{13}$ yield $=20 \% .-\operatorname{IR}\left(\mathrm{KBr}, \mathrm{cm}^{-1}\right): \bar{v}_{\max }=$ 3024, 2948-2985, 2848-2900, 1728, 1662. - ${ }^{1} \mathrm{H} \mathrm{NMR}\left(\mathrm{CDCl}_{3}\right): \delta=1.35$ (t, $\left.\mathrm{J}=7.0 \mathrm{~Hz}, 3 \mathrm{H}, \mathrm{CH}_{3}\right), 3.86\left(\mathrm{~s}, 3 \mathrm{H}, 5-\mathrm{OCH}_{3}\right), 3.89\left(\mathrm{~s}, 3 \mathrm{H}, 3-\mathrm{OCH}_{3}\right)$, 4.38 (q, 2H, J=7.0 Hz, CH $), 6.50(\mathrm{~d}, 1 \mathrm{H}, J=2.0 \mathrm{~Hz}, 4-\mathrm{H}), 6.56(\mathrm{~d}$, $1 \mathrm{H}, J=2.0 \mathrm{~Hz}, 6-\mathrm{H}), 10.29$ (s, $1 \mathrm{H}, \mathrm{CHO}) .-{ }^{13} \mathrm{C} \mathrm{NMR}\left(\mathrm{CDCl}_{3}\right): \delta=$ $13.9\left(\mathrm{CH}_{3}\right), 55.8\left(5-\mathrm{OCH}_{3}\right), 56.0\left(3-\mathrm{OCH}_{3}\right), 61.9\left(\mathrm{CH}_{2}\right), 99.5(\mathrm{C}-4)$, 105.2 (C-6), 116.7 (C-2), 137.0 (C-1), 163.2 (C-3), 165.0 (C-5), 169.0 $(\mathrm{C}=\mathrm{O}) ; 187.6(\mathrm{CH}=\mathrm{O})$. The NMR data were compared to literature. ${ }^{13}$

\section{3,5-dimethoxyphthalide $(\mathbf{6})^{13}$}

M.p. $=165^{\circ} \mathrm{C}$ (lit., $\left.167^{\circ} \mathrm{C}\right) ;{ }^{13}$ yield $=94 \% .-\operatorname{IR}\left(\mathrm{KBr}, \mathrm{cm}^{-1}\right): \bar{v}_{\max }$ = 3006-3087, 2842-2950, 1751. $-{ }^{1} \mathrm{H} \mathrm{NMR}\left(\mathrm{CDCl}_{3}\right): \delta=3.84(\mathrm{~s}, 3 \mathrm{H}$, $\left.5-\mathrm{OCH}_{3}\right), 3.85\left(\mathrm{~s}, 3 \mathrm{H}, 3-\mathrm{OCH}_{3}\right), 5.18\left(\mathrm{~s}, 2 \mathrm{H}, \mathrm{CH}_{2}\right), 6.66(\mathrm{~d}, 1 \mathrm{H}, \mathrm{J}=$ $1.6 \mathrm{~Hz}, 4-\mathrm{H}), 6.91(\mathrm{~d}, 1 \mathrm{H}, J=1.6 \mathrm{~Hz}, 5-\mathrm{H}) .-{ }^{13} \mathrm{C} \mathrm{NMR}\left(\mathrm{CDCl}_{3}\right): \delta=$ $55.6\left(3-\mathrm{OCH}_{3}\right), 55.9\left(5-\mathrm{OCH}_{3}\right), 68.0\left(\mathrm{CH}_{2}\right), 98.6(\mathrm{C}-6), 104.8(\mathrm{C}-4)$, $127.9(\mathrm{C}-1), 128.2(\mathrm{C}-2), 154.9(\mathrm{C}-3), 162.5(\mathrm{C}-5), 171.3(\mathrm{C}=\mathrm{O})$. The NMR data were compared to literature. ${ }^{13}$

\section{3,5-dimethoxyphthalic acid (7) ${ }^{17}$}

To an aqueous solution of $\mathrm{NaOH} 2 \mathrm{~N}(1 \mathrm{~mL})$ was added compound $6(0.26 \mathrm{mmol})$ and the mixture was heated in a water bath for $10 \mathrm{~min}$. Following the reaction was cooled to $0{ }^{\circ} \mathrm{C}$ and an aqueous solution of $\mathrm{KMnO}_{4} 6 \%(1 \mathrm{~mL})$ was added and the mixture was stirred for $13 \mathrm{~h}$ at temperature around $0{ }^{\circ} \mathrm{C}$, allowed to warm to room temperature and stirred for additional $75 \mathrm{~h}$. Ethanol $(1 \mathrm{~mL})$ was poured to the mixture to consume the remaining $\mathrm{KMnO}_{4}$ and then evaporated at reduced pressure. Aqueous solution of $\mathrm{HCl} 1 \mathrm{M}$ was added until $\mathrm{pH}=1$. The reaction mixture was transferred to a dropping funnel and extracted with ethyl acetate $(2 \times 15 \mathrm{~mL})$. The organic layer was washed with water $(3 \times 15 \mathrm{~mL})$, brine $(3 \times 15$ $\mathrm{mL}$ ), dried over $\mathrm{MgSO}_{4}$ and the solvent was evaporated at reduced pressure to afford compound 7 as white solid. M.p. $=157^{\circ} \mathrm{C}$ (lit., $\left.159{ }^{\circ} \mathrm{C}\right) ;{ }^{18}$ yield $=55 \%$. - IR $\left(\mathrm{KBr}, \mathrm{cm}^{-1}\right): \overline{\mathrm{v}}_{\max }=2400-3400,3456$, 3481, 3008-3076, 2850-2956, 1718, 1691. - ${ }^{1} \mathrm{H}$ NMR (CD 30 ): $\delta$ $=3.73\left(\mathrm{~s}, 3 \mathrm{H}, 5-\mathrm{OCH}_{3}\right), 3.74\left(\mathrm{~s}, 3 \mathrm{H}, 3-\mathrm{OCH}_{3}\right), 6.70(\mathrm{~d}, 1 \mathrm{H}, \mathrm{J}=2.2$ $\mathrm{Hz}, 4-\mathrm{H}), 6.96(\mathrm{~d}, 1 \mathrm{H}, J=2.2 \mathrm{~Hz}, 6-\mathrm{H}) .-{ }^{13} \mathrm{C} \mathrm{NMR}\left(\mathrm{CD}_{3} \mathrm{OD}\right): \delta$ $=56.2\left(5-\mathrm{OCH}_{3}\right), 56.7\left(3-\mathrm{OCH}_{3}\right), 103.4(\mathrm{C}-4), 107.1(\mathrm{C}-6), 120.2$ (C-2), 131.8 (C-1), 159.0 (C-5), 162.6 (C-3), 168.5 (C=O-2), 171.8 $(\mathrm{C}=\mathrm{O}-1)$. The IR data were compared to literature. ${ }^{15}$

\section{3,5-dimethoxyphthalic anhydride (8)}

To compound $7(0.5 \mathrm{mmol})$ was added acetic anhydride $(2 \mathrm{~mL})$. The reaction was kept under reflux and stirring for $1 \mathrm{~h}$. Acetic anhydride was then distilled at reduced pressure to give compound $\mathbf{8}$ as yellowish solid. M.p. $=148{ }^{\circ} \mathrm{C}$ (lit. $\left.149-150{ }^{\circ} \mathrm{C}\right) ;{ }^{19}$ yield $=95 \% .-$ IR $\left(\mathrm{KBr}, \mathrm{cm}^{-1}\right): \bar{v}_{\max }=2400-3400,3087,2848-2997,1839,1766 .-{ }^{1} \mathrm{H}$ $\operatorname{NMR}\left(\mathrm{CDCl}_{3}\right): \delta=3.95$ (s, 3H, 5-OCH$), 4.00$ (s, 3H, 3-OCH $), 6.73$ (d, $1 \mathrm{H}, J=1.2 \mathrm{~Hz}, 4-\mathrm{H}), 7.01$ (d, $1 \mathrm{H}, J=1.2 \mathrm{~Hz}-6-\mathrm{H}) .-{ }^{13} \mathrm{C}$ NMR $\left(\mathrm{CDCl}_{3}\right): \delta=56.5\left(\mathrm{OCH}_{3}-3,5\right), 101.5(\mathrm{C}-4) ; 105.5(\mathrm{C}-6), 110.1(\mathrm{C}-2)$, 135.5 (C-1), 159.4 (C-5), 160.3 (C-3), 168.3 (C=O-1), 163.1 (C=O-2). 
3-heptyl-3-hydroxy-5,7-dimethoxy-2-benzofuran-1(3H)-one (1) and 3-heptyl-3-hydroxy-4,6-dimethoxy-2-benzofuran-1(3H)-one (2)

Grignard reagent was prepared by adding magnesium turnings (1.4 mmol) to anhydrous THF $(1 \mathrm{~mL})$ and dropwise addition of 1-bromoheptane $(3.4 \mathrm{mmol})$ followed by stirring under nitrogen atmosphere for $1 \mathrm{~h}$. Compound $\mathbf{8}(0.44 \mathrm{mmol})$ was dissolved in THF $(1 \mathrm{~mL})$, cooled to $0{ }^{\circ} \mathrm{C}$ and added to initial mixture. The reaction mixture was kept under stirring for $30 \mathrm{~min}$ at $0{ }^{\circ} \mathrm{C}$. Then an aqueous solution of $\mathrm{HCl} 1 \mathrm{M}$ was poured to the reaction flask until $\mathrm{pH}=3$. The mixture was transferred to a dropping funnel and extracted with ethyl acetate $(3 \times 20 \mathrm{~mL})$. The organic layer was washed with $\mathrm{H}_{2} \mathrm{O}$ $(2 \times 10 \mathrm{~mL})$, brine $(2 \times 10 \mathrm{~mL})$ and dried over $\mathrm{MgSO}_{4}$. The solvent was evaporated at reduced pressure and the resulting material was submitted to flash chromatography using ethyl acetate : $n$-hexane $(1: 1)$ as eluent. It was obtained two isomeric compounds. 1 (yield $=20 \%$ ) and 2 (yield $=17 \%$ ). ${ }^{1} \mathrm{H}$ and ${ }^{13} \mathrm{C}$ NMR data are related in Table 1.

\section{Allelopathic activity}

In sterilized Petri dishes were poured on $2 \mathrm{~mL}$ of a solution (ethanol or hexane) of each pure compound to be tested at different concentrations ranging from 1.6 to $10.3 \mathrm{mM}$. The dishes were placed into an incubator at $48^{\circ} \mathrm{C}$ until complete evaporation of the solvent. Then, 25 seeds of $L$. sativa $\mathrm{L}$. were placed on dishes and humidified with phosphate buffer $\mathrm{pH}=6$ (4 mL). Seeds of type Gran Rapids were employed, with $99 \%$ of germination and $99.7 \%$ of purity. Solutions of caffeine were used at concentrations of 61.8 and $123.6 \mathrm{mM}$ as positive control. Negative controls were solvents and assay buffer. All tests were performed in triplicate. It was registered the number of germinated seeds from the first to the third day. Measuring (in $\mathrm{mm}$ ) of the radicle and hypocotyl length was done on the fifth day.

\section{ACKNOWLEDGMENTS}

The authors thank Kardol Ind. Químca Ltda., CNPq (Campo Grande-Brazil) and PROPP-UFMS for financial support. We are also indebt with all UFMS technicians involved in this work, Prof. D. L. J. Clive (University of Alberta-Edmonton-Canada) for providing reference 10 and Dr. P. Melnikov (DFI-UFMS) for translation of the Russian article.

\section{REFERENCES}

1. Kozubek, A.; Tyman, J. H. P. In Studies in Natural Products Chemistry; Atta-ur-Rahman, ed.; Elsevier Science: Karachi, 2005, vol. 30, p. 111.

2. Ayer, W. A.; Browne, L. M.; Lovell, S. H.; Phytochemistry 1983, 22, 2267.

3. Cojocaru, M.; Droby, S.; Glotter, E.; Goldman, A.; Gottlieb, H. E.; Jacoby, B.; Prusky, D.; Phytochemistry 1986, 25, 1093.

4. Kubo, I.; Komatsu, S.; Ochi, M.; J. Agric. Food Chem. 1986, 34, 970.

5. Arisawa, M.; Ohmura, K.; Kobayashi, A.; Morita, N.; Chem. Pharm. Bull. 1989, 37, 2431 .

6. Kubo, I.; Muroi, H.; Himejima, M.; Yamigiwa, Y.; Mera, H. M.; Tokushima, K.; Ohta, S.; Kamikawa, T.; J. Agric. Food Chem. 1993, 41, 1016.

7. Suresh, M.; Raj, R. K.; Curr. Sci. 1990, 59, 477.

8. Ross, A. B.; Chen, Y.; Frank, J.; Swanson, J. E.; Parker, R. S.; Kozubek, A.; Lundh, T.; Vessby, B.; Åman, P.; Kamal-Eldin, A.; J. Nutr. 2004, 134, 506.

9. Kozubek, A.; Zarnowski, R.; Stasiuk, M.; Gubernator, J.; Cell. Mol. Biol. Lett. 2001, 6, 351 .

10. Vobliokova, V. D.; Kobrina, N. S.; Gerasimova, N. M.; Pavlova, Z. N.; Dem'yanova, G. F.; Murygina, V. P.; Volosova, L. I.; Muromtsev, G. S.; Khimiya Prirodnykh Soedinenii 1985, 387. (CA 103:101555)

11. Vogel, A. I.; Vogel's Textbook of Practical Organic Chemistry, $5^{\text {th }}$ ed., Longman Scientific \& Techinical: New York, 1989.

12. Garbaccio, R. M.; Stachel, S. J.; Baeschlin, D. K.; Danishefsky, S. M.; Gasiorowski, K.; J. Am. Chem. Soc. 2001, 123, 10903.

13. Paradkar, M. V.; Kulkarni, S. A.; Joseph, A. R.; Ranade, A. A.; J. Chem. Res. (S) 2000, 364.

14. Casellas, D. M.; Avellana, J. P.; Perez, M. L.; Benet, A. P.; Calahorra, F. L.; Via, J. M.; Carbo, B. B.; ES 2163986 A1, 2002. (CA 138:254958)

15. AIST: Integrated Spectral Database System of Organic Compounds (Data were obtained from the National Institute of Advanced Industrial Science and Technology (Japan).

16. Nelson, L.; Getsinger, K. D.; J. Aquat. Plant Manage. 2000, 38, 70.

17. Brokmann, H.; Kluge, F.; Muxfeldt, H.; Chemische Berichte 1957, 90, 2302.

18. Logan, W. R.; Newbold, G. T.; J. Chem. Soc. 1957, 32, 1946.

19. Bruun, T.; Acta Chem. Scand. 1965, 19, 1677. 